\title{
Removal of Cr (VI) and Cr (III) From Polluted Water and Soil Sown with Beet (Beta vulgaris) or Celery (Apium graveolens) after the Addition of Modified Zeolites
}

\author{
Evangelia Brozou ${ }^{1}$, Zacharias loannou ${ }^{2 *}$ and Anthoula Dimirkou ${ }^{1}$ \\ ${ }^{1}$ Soil Science Laboratory, Department of Agriculture, Crop Production and Rural Environment, School of Agricultural Sciences, University of Thessaly, N. Ionia Volos, \\ 38446, Magnesia, Greece \\ ${ }^{2}$ University of the Aegean, Mitropoliti loakim 2, Myrina, 81400, Lemnos, Greece \\ "Corresponding author: Zacharias loannou, University of the Aegean, Mitropoliti loakim 2, Myrina, 81400, Lemnos, Greece, Tel: +30-22540-83122; Fax: \\ +30-22540-83109; E-mail: zioan@teemail.gr
}

Received date: September 29, 2018; Accepted date: October 24, 2018; Published date: October 31, 2018

Copyright: @ 2018 Brozou E, et al. This is an open access article distributed under the terms of the Creative Commons Attribution License, which permits unrestricted use, distribution and reproduction in any medium, provided the original author and source are credited.

\begin{abstract}
Clinoptilolite, which was modified with hexadecyltrimethylammonium-bromide solution (HDTMA-Br) in a proportion of $1 / 8 \mathrm{w} / \mathrm{v}(\mathrm{Z1})$, was applied for the adsorption of chromate anions from aqueous solutions. Different initial concentrations of chromate anions from 0 to $145 \mathrm{ppm}$ were added as $\mathrm{K}_{2} \mathrm{Cr}_{2} \mathrm{O}_{7}$ to $1 \mathrm{~g}$ of modified zeolite adsorbent. Zeolite (clinoptilolite, $Z$ ) was also used for comparison reasons. The kinetic analysis of both adsorbents $(Z, Z 1)$ was studied at $25^{\circ} \mathrm{C}$. Equilibrium isotherms of chromate anions were studied for clinoptilolite and modified zeolite at 25 , 40 and $60^{\circ} \mathrm{C}$. According to the kinetic analysis, the chromate anions adsorption capacity reached at $1115.10 \mathrm{mg} \mathrm{Cr}$ $(\mathrm{VI}) / \mathrm{kg}$ adsorbent for Z1 and $35.05 \mathrm{mg} \mathrm{Cr}(\mathrm{VI}) \mathrm{kg}$ for $\mathrm{Z}$. According to isotherms, the adsorption of $\mathrm{Cr}(\mathrm{VI})$ on Z1 and Z did not increase with the increase of temperature indicating that the whole adsorption mechanism is controlled by chemisorption and not by physical adsorption. Modified zeolite and zeolite were tested to two different soils, i.e. a sandy loam soil and a silty loam soil polluted with $\mathrm{Cr}(\mathrm{VI})$ and sown with beet (Beta vulgaris) or celery (Apium graveolens ). $\mathrm{Cr}(\mathrm{VI})$ concentration decreased significantly to the upper part of celery and beet with the addition of soil amendments. The modification of clinoptilolite with HDTMA-Br leads to the creation of positively charged surface sites of zeolite increasing the adsorption of $\mathrm{Cr}(\mathrm{VI})$ as chromate anions. Such adsorbents can be applied for the removal of heavy metals and dyes in an anionic form from wastewater and soil solutions where negative charged sites of clinoptilolite present low adsorption capacity.
\end{abstract}

Keywords Adsorption; Clinoptilolite; Chromium; HDTMA-Br; Beet; Celery

\section{Introduction}

Contamination of waters and soils with heavy metal ions has become an environmental hazard due to their non-biodegradability and accumulation to living organisms [1]. One of the most abundant contaminant is hexavalent chromium, $\mathrm{Cr}(\mathrm{VI})$, which is soluble and mobile [2]. It can be leached immediately and easily stay in the groundwater and subsoil. Many industries produce effluents with high concentrations of chromium in different oxidation states during the processes of chrome plating, textile and paper manufacturing, stainless steel production, leather tanning [3,4]. The treatment of effluents before discharging them into the environment becomes necessary. One of the most promising method for the removal of contaminants is adsorption where a variety of materials were used as adsorbents, e.g. minerals, carbons $[5,6]$.

Zeolites are present in many areas of Greece but the deposits of high financial interest are found in the following three regions, a) the province of Thrace with deposits reach in heulandite and/or clinoptilolite, b) the islands of Kimolos and Poliegos with deposits rich in mordenite and c) the island of Samos with deposits rich in clinoptilolite and/or analcite [7]. Zeolites are aluminosilicate minerals with basic structural units of tetrahedral $\mathrm{SiO}_{4}$ and $\mathrm{AlO}_{4}$. An amount of quadric-charged silicon is replaced by triply-charged aluminium leading to a net negative charge of the framework. The framework is counterbalanced by cations such as $\mathrm{Na}^{+}, \mathrm{K}^{+}, \mathrm{Ca}^{2+}, \mathrm{Mg}^{2+}$ and others placed in the cages and channels [8]. These positive ions can readily be exchanged with others in a bulk solution creating a unique cation exchange capacity (CEC). The permanent negative charge in zeolite crystal structure makes it suitable for the adsorption of cationic surfactants [9]. The ratio of Si to $\mathrm{Al}$ within the zeolite structure is an important factor that classifies zeolites to three categories: low Si:Al ratio (1-1.5), intermediate Si:Al ratio (2-5) and high Si:Al ratio (10 and above). Increasing the Si:Al ratio, the hydrothermal stability and hydrophobicity increases. The higher the ratio $\mathrm{Si}: \mathrm{Al}$ in zeolite framework, the higher the CEC ability is observed [10].

Although zeolites show a high cation exchange capacity, they present a limited adsorption of anions in their surfaces. Surface modification of zeolites was carried out with organic compounds in order to increase their anion exchange capacity. One of the most widely employed organic modifiers is hexadecyltrimethylammonium (HDTMA), an aliphatic hydrocarbon with a hydrophobic alkyl long 
tail and a hydrophilic quaternary ammonium cation charged part. Br or $\mathrm{Cl}^{-}$salts of HDTMA are used for mineral and clay surface modification. The HDTMA units aggregated on the external zeolite surface creating a bilayer and covering or blocking some of the zeolitic pores. As a result the modification of zeolite with HDTMA decreased its surface area and pore volume and increased its average pore size [11].

In the present paper zeolite (Z1) was modified with hexadecyltrimethylammo-niumbromide solution (HDTMA-Br) so as to be applied for the removal of $\mathrm{Cr}$ (VI) ions from polluted waters. Clinoptilolite $(\mathrm{Z})$ was also used for comparison reasons. The kinetic analysis of both adsorbents $(\mathrm{Z}, \mathrm{Z1})$ was studied at $25^{\circ} \mathrm{C}$. Equilibrium isotherms of $\mathrm{Cr}$ (VI) ions were studied at 25,40 and $60^{\circ} \mathrm{C}$. The adsorbents $(\mathrm{Z1}, \mathrm{Z})$ were tested as amendments to two soils, i.e. a sandy loam and a silty loam soil polluted with $\mathrm{Cr}$ (VI) and sown with beet (Beta vulgaris) or celery (Apium graveolens).

\section{Materials and Methods}

\section{Materials}

Zeolite (clinoptilolite) was obtained from S and B Company. It was modified by using $0.05 \mathrm{~N}$ hexadecyltrimethylammoniumbromide solution (HDTMA-Br) in a proportion of $1 / 8 \mathrm{w} / \mathrm{v}$ (called as modified zeolite, Z1). More specifically, the mixture of clinoptilolite and HDTMA-Br solution $(0.05 \mathrm{~N})$ was stirred with a magnetic stirrer for $24 \mathrm{~h}$, separated by filtration and rinsed with deionized water until the electrical conductivity to fall to $53.7 \mu \mathrm{S} / \mathrm{cm}$ and then dried in an oven at $110^{\circ} \mathrm{C}[12]$.

The adsorption ability of modified zeolite was tested using $1.0 \mathrm{~g}$ of $\mathrm{Z} 1$ and $20 \mathrm{ml}$ of ten different concentrations (from 0 to $145 \mathrm{ppm}$ ) of $\mathrm{K}_{2} \mathrm{Cr}_{2} \mathrm{O}_{7}$ solution. Samples were shaken in a water bath at $25^{\circ} \mathrm{C}$ for 24 $h$. The samples reached at equilibrium after this period and then were centrifuged at $3000 \mathrm{rpm}$ for $10 \mathrm{~min}$. Total chromium in the supernatant was determined using an atomic absorption spectrometer (Perkin Elmer 3300). The adsorbed total chromium from each material was calculated from the difference between the initial chromium concentration and the concentration of chromium at equilibrium according to the following equation [13]:

$$
X_{t}=\frac{\left(C_{\text {initial } \_r}-C_{e_{-} C r}\right) * V}{m}
$$

Where $\mathrm{X}_{\mathrm{t}}$ is the adsorbed amount of chromate ions from each adsorbent, $\mathrm{C}_{\text {initial_Cr }}$ is the initial concentration of chromate ions added to the solution and $\mathrm{Ce}_{-} \mathrm{Cr}$ is the equilibrium concentration of chromate ions in the solution, $\mathrm{V}$ is the volume of solution and $\mathrm{m}$ is the mass of adsorbent. The $\mathrm{pH}$ values of $\mathrm{Cr}$ concentration at equilibrium were on average $8.03+0.10$ and $7.95+0.10$, for zeolite $(Z)$ and modified zeolite $(\mathrm{Z} 1)$, respectively. The whole procedure was done in triplicate. The ability of $\mathrm{Z}, \mathrm{Z} 1$ to adsorb chromate ions was also examined at higher temperatures, i.e. 40 and $60^{\circ} \mathrm{C}$. Zeolite (clinoptilolite) was used for comparison reasons. The kinetic analysis of $\mathrm{Cr}$ adsorption on the two adsorbents was also studied with initial concentration equal to 60 ppm at $25^{\circ} \mathrm{C}$.

\section{Soil experiments}

A soil pot experiment was conducted with beet plants (Beta vulgaris) or celery plants, ( Apium graveolens), in a plastic greenhouse without heating at the farm of the University of Thessaly (Central Greece). Plastic pots of $2 \mathrm{~L}$ in volume were used having perlite in the bottom for better soil aeration. The soil was obtained from the surface layer $(0-30 \mathrm{~cm})$ of the farm, ground and sieved to less than $2 \mathrm{~mm}$. Two types of soils were used: sandy loam and silty loam. The soil parameters appeared in Table 1.

\begin{tabular}{|c|c|c|}
\hline Soil parameters & Sandy loam soil & Silty loam soil \\
\hline Electric Conductivity $(\mu \mathrm{S} / \mathrm{cm})$ & 179 & 240.8 \\
\hline $\mathrm{pH}$ & 8.35 & 8.3 \\
\hline $\mathrm{CaCO}_{3}(\%)$ & 1.78 & 1.9 \\
\hline Organic matter & 0.8 & 0.61 \\
\hline
\end{tabular}

Table 1: Soil properties of sandy loam and silty loam soil.

The ratio of soil/adsorbent was $200 / 1 \mathrm{~g} / \mathrm{g}$. Soil amendments were added fully mixed in the soil and then the mixture was placed to pots. Beet or celery seeds were sown directly in pot soil on October $10^{\text {th }}$, 2013. Cr (VI) in the form of $\mathrm{CrO}_{3}$, was added to the soil at three different doses of $10 \mathrm{mg} \mathrm{Cr}(\mathrm{VI}) / \mathrm{kg}$ soil 15,20 and 22 days after sowing. Fertilization (Entec 26-0-0+13S, EuroChem Agro GmbH) took place on October $23^{\text {th }}, 2013.0 .5 \mathrm{~g}$ of the fertilizer was applied to each pot. The water storage capacity of soil remained stable at $65 \%$ and the temperature ranged from 25 to $35^{\circ} \mathrm{C}$. The experiment repeated six times.

\begin{tabular}{|c|c|c|c|c|c|}
\hline \multirow{2}{*}{ Treatment } & \multicolumn{2}{|c|}{ Amendment } & \multicolumn{2}{c|}{ Types of soil } & \multirow{2}{*}{ Cr(VI) } \\
\cline { 2 - 6 } & Z & Z1 & $\begin{array}{c}\text { Sandy } \\
\text { loam }\end{array}$ & $\begin{array}{c}\text { Silty } \\
\text { loam }\end{array}$ & \\
\hline SZ & $\mathrm{x}$ & - & $\mathrm{x}$ & - & $\mathrm{x}$ \\
\hline SMZ & - & $\mathrm{x}$ & $\mathrm{x}$ & - & $\mathrm{x}$ \\
\hline S & - & - & $\mathrm{x}$ & - & $\mathrm{x}$ \\
\hline $\mathrm{C}$ & - & - & $\mathrm{x}$ & - & - \\
\hline SZ & $\mathrm{x}$ & - & - & $\mathrm{x}$ & $\mathrm{x}$ \\
\hline SMZ & - & $\mathrm{x}$ & - & $\mathrm{x}$ & $\mathrm{x}$ \\
\hline $\mathrm{S}$ & - & - & - & $\mathrm{x}$ & $\mathrm{x}$ \\
\hline $\mathrm{C}$ & - & - & - & $\mathrm{x}$ & - \\
\hline
\end{tabular}

Table 2: Schematic representation of greenhouse experiments.

Twenty four treatments were realized, i.e. six with soil containing $\mathrm{Cr}$ (VI) named as S, six with soil, zeolite as soil amendment and Cr (VI) named as SZ, six with soil, modified zeolite as soil amendment and $\mathrm{Cr}$ (VI) named as SMZ and six with soil without $\mathrm{Cr}$ (VI) named as $\mathrm{C}$ (control) (Table 2). The duration of the experiment was 3 months and 18 days (until January 28th, 2014). At the end of the experiment, the plants were dried in an oven at $70^{\circ} \mathrm{C}$ for $48 \mathrm{~h}$, milled into fine powder 
Citation: Brozou E, loannou Z, Dimirkou A (2018) Removal of $\mathrm{Cr}$ (VI) and $\mathrm{Cr}$ (III) From Polluted Water and Soil Sown with Beet (Beta vulgaris) or Celery (Apium graveolens) after the Addition of Modified Zeolites. Int J Waste Resour 8: 359. doi:10.4172/2252-5211.1000359

Page 3 of 8

and stored in plastic bags for further analysis. Air-dried soil samples were sieved through a $2 \mathrm{~mm}$ sieve and analyzed for total (aqua regia$\mathrm{HCL}-\mathrm{HNO}_{3}$ in a proportion of $75: 25 \% \mathrm{w} / \mathrm{w}$ digested, [14]) and available $\mathrm{Cr}(\mathrm{III})$ content, extracted with diethylenetriaminepentaacetic acid (DTPA) (according to Lindsay and Norvell [15]) using a Perkin Elmer 3300 atomic absorption spectrophotometer. For the determination of the exchangeable $\mathrm{Cr}(\mathrm{VI})$ in soil, soil samples were extracted with $0.01 \mathrm{M} \mathrm{KH}_{2} \mathrm{PO}_{4}$ and to the extractants, developed color by the diphenyl carbazide method. The extractants were then analyzed using a Shimadzu UV-Vis 120-01 spectrophotometer at $540 \mathrm{~nm}$. Total chromium in crops were determined with Perkin Elmer 3300 atomic absorption spectrophotometer after the dry-washing procedure of $1 \mathrm{~g}$ of each plant sample at $520^{\circ} \mathrm{C}$ for $24 \mathrm{~h}$ and the ash washing with $20 \mathrm{~mL}$ of $20 \%$ HCL. The differences among treatments were compared according to the LSD test for a level of significance of $95 \%$ using the Statgraphics plus 5.1 packages (Multifactor ANOVA/Multiple range tests). If the absolute difference between any two treatment means is more than the LSD value, the treatments are said to be significantly different at the $5 \%$ confidence level. Significantly different treatments are labeled with different lowercase letters while non-significant differences share the same lowercase letter $[16,17]$.

\section{Results and Conclusion}

The adsorbed chromium amount on each material in correlation with different time intervals is presented to Figure 1. It seems that $\mathrm{Z1}$ adsorbent presented higher adsorption of chromate ions than $\mathrm{Z}$ due to the presence of HDTMA ions, which create positive charge sites in the zeolitic surface. As a result modified zeolite consists of positive sites in a negative charged surface presenting simultaneously a cation and anion exchange capacity. Furthermore, Figure 2 depicts the adsorbed amount of chromate ions per kilogram of adsorptive material in correlation with the initial concentration of chromium at 25, 40 and $60^{\circ} \mathrm{C}$. It seems that the total chromium uptake increased with the increase of initial total chromium concentration in the solution from 0 to $145 \mathrm{mgL}^{-1}$. $\mathrm{Z} 1$ presented the maximum adsorption of chromate ions ( $\left.2000 \mathrm{mg} \mathrm{Cr}(\mathrm{VI}) \mathrm{kg}^{-1}\right)$, while $\mathrm{Z}$ presented the minimum adsorption of chromate ions ( 35.00 mg Cr (VI) kg-1).

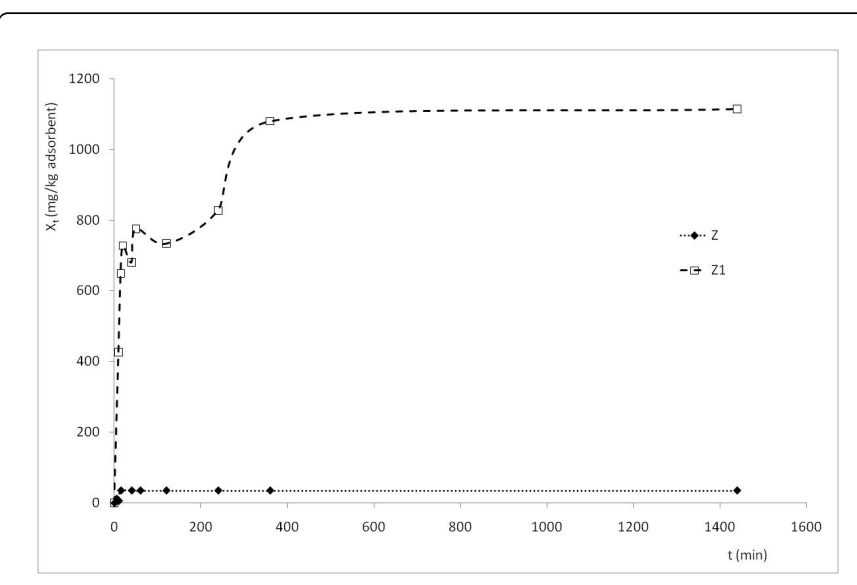

Figure 1: Adsorption of total chromium from its aqueous solutions per kg of modified zeolite or zeolite versus time $t$ at $25^{\circ} \mathrm{C}$.

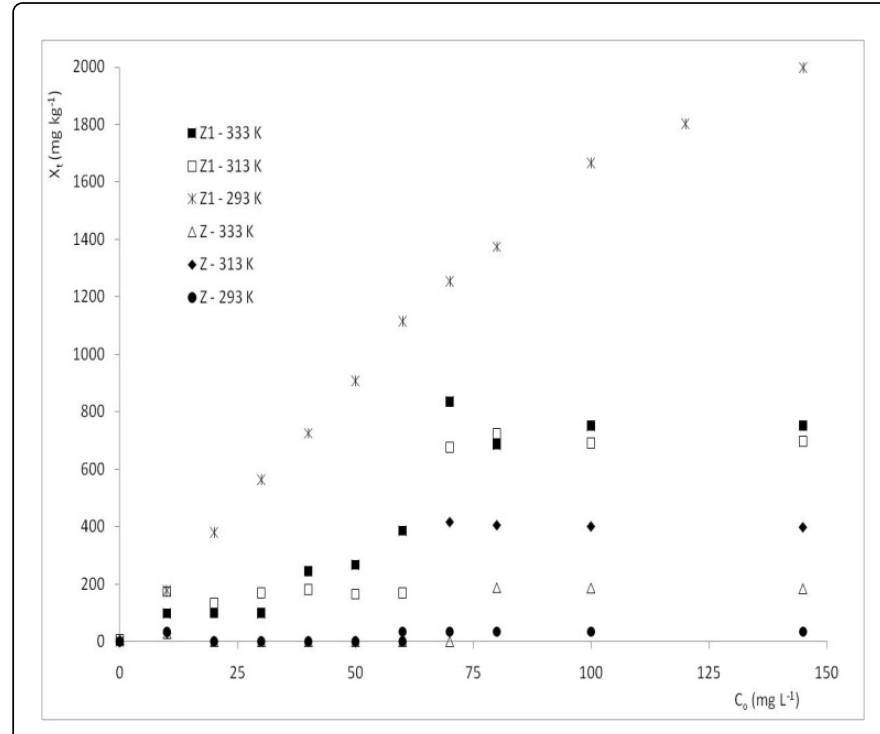

Figure 2: Uptake of total chromium from aqueous solutions onto modified zeolite and zeolite at different temperatures and initial concentrations.

Specifically, total chromium uptake on $\mathrm{Z} 1$ reached up to $751.31 \mathrm{mg}$ $\mathrm{Kg}^{-1}$ for initial chromium concentration equal to $100 \mathrm{mg} \mathrm{Kg}^{-1}$ at $60^{\circ} \mathrm{C}$, while the adsorbed chromium amount on $\mathrm{Z} 1$ at $40^{\circ} \mathrm{C}$ reached at 690.56 $\mathrm{mg} \mathrm{Kg}{ }^{-1}$ for the same initial chromium concentration. Furthermore, the amount of chromium uptake was $2000.01 \mathrm{mg} \mathrm{Kg}^{-1}$ for modified zeolite at $145 \mathrm{mg} \mathrm{L}^{-1}$ and $25^{\circ} \mathrm{C}$. The order of chromate uptake onto modified zeolite follows: $20>60>40^{\circ} \mathrm{C}$ indicating that temperature did not influence the adsorption process and simultaneously did not increase the diffusion of chromate ions on the adsorbent. As a result the whole mechanism of adsorption is controlled by chemisorption and not by physical adsorption. As far as zeolite may concern, it seems that up to $60 \mathrm{mg} \mathrm{L}^{-1}$ of initial total chromium concentration no ions adsorption took place on zeolite and then small amounts of chromate ions were adsorbed. In addition, the $\mathrm{HCrO}_{4}^{-}$ions are most easily exchanged with $\mathrm{OH}^{-}$ions at active surfaces under acidic conditions. In high $\mathrm{pH}$ values, the interference by a high concentration of $\mathrm{OH}^{-}$ions may lead to lower removal efficiency. Increased amounts of $\mathrm{OH}^{-}$, increases the competition between $\mathrm{Cr}$ (VI) and $\mathrm{OH}$ for occupying exchange sites in absorbent pore [18]. Brozou et al. [19] compared zeolites, which were modified with HDTMA-Br in a proportion of $1 / 8$ and $1 / 4 \mathrm{w} / \mathrm{v}$ showing that the first adsorbent presented a percentage of 75 to $95 \%$ of chromate anions uptake while the second one presented a percentage equal to $10-32 \%$. Four different model isotherms were applied to the experimental data, i.e. Langmuir, Freundlich, Temkin and Dubinin-Radushkevich [19]. According to the results the adsorption data from zeolite are best described by Langmuir isotherm while the adsorption data from modified zeolite are best described by Langmuir and Temkin isotherm. The Langmuir isotherm model is based on the assumption that the adsorbent sites are covered with $\mathrm{Cr}$ (VI) ions creating a monolayer surface coverage and no further adsorption occurs at those sites [20,21]. The adsorption is characterized by a single binding energy. The linear form of the Langmuir expression follows:

$$
1 / \mathrm{X}_{\mathrm{e}}=1 /\left(\mathrm{K}_{\mathrm{L}} \times \mathrm{X}_{\mathrm{m}} \times \mathrm{Ce}_{\mathrm{e}}\right)+1 / \mathrm{X}_{\mathrm{m}}
$$


where: $\mathrm{Ce}\left(\mathrm{mg} \mathrm{L}^{-1}\right)$ is the equilibrium concentration of chromate ions $\mathrm{X}_{\mathrm{e}}\left(\mathrm{mg} \mathrm{Cr} \mathrm{kg}^{-1}\right)$ is the amount of chromate ions adsorbed per unit mass of adsorbent in equilibrium, $\mathrm{K}_{\mathrm{L}}\left(\mathrm{Lmg}^{-1}\right)$ is a constant related to the energy of adsorption and $\mathrm{Xm}_{\mathrm{m}}\left(\mathrm{mg} \mathrm{Cr} \mathrm{kg}^{-1}\right)$ is the maximum adsorption of chromate ions per unit mass of adsorbent. The slope and intercept of the plot $1 / \mathrm{X}_{\mathrm{e}}$ versus $1 / \mathrm{Ce}_{\mathrm{e}}$ lead to the values of $\mathrm{KL}_{\mathrm{L}}$ and $\mathrm{Xm}_{\mathrm{m}}$, respectively. The dimensionless separation factor, $\mathrm{R}_{\mathrm{L}}$, was also evaluated using $\mathrm{K}_{\mathrm{L}}$ values according to the following equation:

$$
\mathrm{R}_{\mathrm{L}}=1 /\left(1+\mathrm{K}_{\mathrm{L}} \mathrm{C}_{\mathrm{o}}\right)
$$

Where $\mathrm{Co}_{\mathrm{o}}$ is the initial concentration of adsorbate. The values of $\mathrm{R}_{\mathrm{L}}$ can be used for the interpretation of the adsorption type showing that when $R_{L}=0$ the adsorption is irreversible, $R_{L}>1$ the adsorption is unfavorable and $0<\mathrm{R}_{\mathrm{L}}<1$ the adsorption is favorable $[13,22]$. The Temkin model assumes that the heat of adsorption of all the molecules in the layer decreases linearly with coverage due to adsorbentadsorbate interactions, and that the adsorption is characterized by a uniform distribution of the binding energies, up to some maximum binding energy. Temkin model is given as follows:

$$
\mathrm{X}_{\mathrm{e}}=(\mathrm{RT} / \mathrm{b}) \times \ln \left(\mathrm{KT}_{\mathrm{T}} \mathrm{Ce}\right) \text { or } \mathrm{Xe}_{\mathrm{e}}=(\mathrm{RT} / \mathrm{b}) \times \ln \mathrm{K}_{\mathrm{T}}+(\mathrm{RT} / \mathrm{b}) \times \ln \mathrm{Ce}_{\mathrm{e}}(4)
$$

Where $\mathrm{T}$ is the absolute temperature $(\mathrm{K}), \mathrm{R}$ is the universal gas constant; $\mathrm{KT}_{\mathrm{T}}\left(\mathrm{Lmg}^{-1}\right)$ is the equilibrium binding constant corresponding to the maximum binding energy, $\mathrm{b}\left(\mathrm{kJ} \mathrm{mol}^{-1}\right)$ is Temkin isotherm constant, $\mathrm{RT} / \mathrm{b}$ (dimensionless) is related to the heat adsorption [23]. The results have shown that the Langmuir parameters for zeolite and modified zeolite are the following: $\mathrm{Z}, \mathrm{K}_{\mathrm{L}}$ (L $\left.\mathrm{mg}^{-1}\right)=0.118, \mathrm{X}_{\mathrm{m}}(\mathrm{mg} \mathrm{kg}-1)=35.050, \mathrm{R}_{\mathrm{L}}=0.055-1.000, \mathrm{R}^{2}=0.997, \mathrm{Z} 1, \mathrm{KL}$ $\mathrm{KL}_{\mathrm{L}}\left(\mathrm{L} \mathrm{mg}^{-1}\right)=0.302, \mathrm{Xm}_{\mathrm{m}} \quad\left(\mathrm{mg} \mathrm{kg}^{-1}\right)=2000.02, \mathrm{R}_{\mathrm{L}}=0.055-1.000, \mathrm{R}^{2}=0.997$ and the Temkin parameters are the following: $\mathrm{Z1}, \mathrm{b}\left(\mathrm{kJ} \mathrm{mol}^{-1}\right)=0.006$, $\mathrm{K}_{\mathrm{T}}\left(\mathrm{L} \mathrm{mg}^{-1}\right)=4.746, \mathrm{R}^{2}=0.991$, where $\mathrm{R}^{2}$ is the correlation coefficient factor [19].

In an aqueous solution, chromate ions are influenced by different parameters such as $\mathrm{pH}$ and concentration creating different ionic forms. The $\mathrm{Cr}(\mathrm{VI})$ species may be presented in various forms such as $\mathrm{H}_{2} \mathrm{CrO}_{4}, \mathrm{HCrO}_{4}, \mathrm{CrO}_{4}{ }^{2-}$ and $\mathrm{Cr}_{2} \mathrm{O}_{7}{ }^{2-}$ in the solution phase at different $\mathrm{pH}$ values according to the following reactions [24]:

$$
\begin{aligned}
& \mathrm{HCrO}_{4}^{-} \leftrightarrow \mathrm{CrO}_{4}^{2-}+\mathrm{H}^{+}(1), \mathrm{H}_{2} \mathrm{CrO}_{4} \leftrightarrow \mathrm{HCrO}_{4}^{-}+\mathrm{H}^{+}(2), \mathrm{Cr}_{2} \mathrm{O}_{7}{ }^{2-} \\
+ & \mathrm{H}_{2} \mathrm{O} \leftrightarrow 2 \mathrm{HCrO}_{4}^{-}
\end{aligned}
$$

Baes and Mesmer [25], mentioned that between $\mathrm{pH} 2$ and 6, $\mathrm{HCrO}_{4}^{-}$, and dichromate ion, $\mathrm{Cr}_{2} \mathrm{O}_{7}^{2-}$, are present in equilibrium while above $\mathrm{pH} 6$, the dominant species are $\mathrm{CrO}_{4}{ }^{2-}$. Below $\mathrm{pH} 1$, the $\mathrm{Cr}$ (VI) species are presented as $\mathrm{HCr}_{2} \mathrm{O}_{7}{ }^{-}$ions. According to the solution $\mathrm{pH}$, the $\mathrm{HCrO}_{4}^{-}, \mathrm{Cr}_{2} \mathrm{O}_{7}{ }^{2-}, \mathrm{CrO}_{4}{ }^{2-}$ and $\mathrm{HCr}_{2} \mathrm{O}_{7}^{-}$ions displace the surfactant counter ion from the exchange sites on the clays forming Clin-HDTMA- $\mathrm{HCrO}_{4}$, (Clin-HDTMA) $)_{2}-\mathrm{Cr}_{2} \mathrm{O}_{7}$, (Clin-HDTMA) $)_{2}$ - $\mathrm{CrO}_{4}$ or Clin-HDTMA- $\mathrm{HCr}_{2} \mathrm{O}_{7}$ respectively, where Clin-HDTMA- is the modified clinoptilolite with HDTMA-Br exchanging $\mathrm{Br}$ - ions with the different species of chromate ions [26]. According to chromium concentrations in the solution particular chromate species will predominate. The bichromate ions $\left(\mathrm{Cr}_{2} \mathrm{O}_{7}{ }^{2-}\right)$ dominate in acidic environments for chromium concentrations higher than $500 \mathrm{mgL}^{-1}$, while the $\mathrm{HCrO}_{4}^{-}$and $\mathrm{CrO}_{4}{ }^{2-}$ oxyanions dominate at concentrations below $500 \mathrm{mgL}^{-1}$. In the present study chromium concentration is below $500 \mathrm{mg} / \mathrm{L}$ and subsequently $\mathrm{HCrO}_{4}{ }^{-}$and $\mathrm{CrO}_{4}{ }^{2-}$ oxyanions dominate. Moreover, the $\mathrm{pH}$ values range from 7.9 to 8.0 for all adsorbents indicating that $\mathrm{CrO}_{4}{ }^{2-}$ are predominant and were adsorbed by modified zeolite in the form of (Clin-HDTMA $)_{2}-\mathrm{CrO}_{4}$.

At lower $\mathrm{pH}$, the univalent form $\left(\mathrm{HCrO}_{4}^{-}\right)$of $\mathrm{Cr}(\mathrm{VI})$ species is predominant requiring one exchange site for one molecule of $\mathrm{Cr}$ (VI) species while at higher $\mathrm{pH}$, the divalent form of $\mathrm{Cr}$ (VI) species $\left(\mathrm{Cr}_{2} \mathrm{O}_{7}{ }^{2-}, \mathrm{CrO}_{4}{ }^{2-}\right)$ are mostly present and need two exchange sites of modified zeolite surface for the adsorption to take place [24]. Consequently modified zeolite shows higher removal capacity of $\mathrm{Cr}$ (VI) species at lower $\mathrm{pH}$ than that at higher $\mathrm{pH}$. The negative charged chromate ions are sorbed by the positively charged head group of HDTMA layer only when the sorbed HDTMA molecules form bilayers or patchy bilayers and chromate has a stronger affinity for the positively charged HDTMA head group than for the counter-ions already sorbed (Figure 3). The bilayer coverage is most complete when $\mathrm{Br}^{-}$is the counterion than other counter-ions such as $\mathrm{Cl}^{-}, \mathrm{HSO}_{4}^{-}$[27].

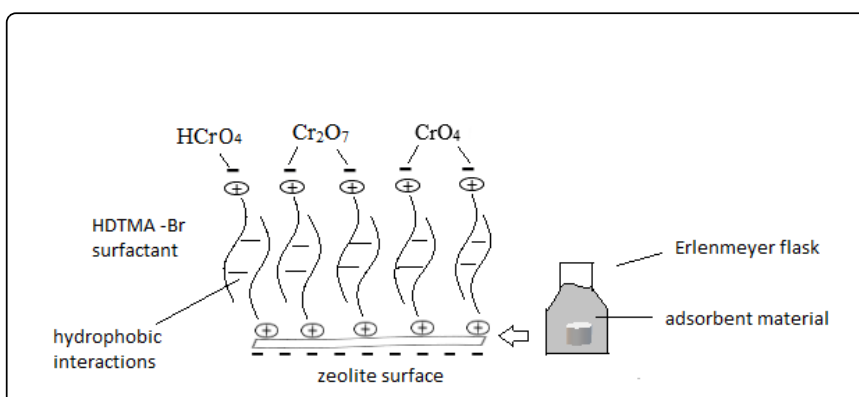

Figure 3: Schematic representation of different chromate species uptake onto zeolite modified with HDTMA-Br solution.

Furthermore, at $\mathrm{pH} 10$ there is a strong competition between $\mathrm{OH}^{-}$ and $\mathrm{Br}^{-}$or chromate anion for the sorption sites of $\mathrm{Z} 1$ since more $\mathrm{OH}^{-}$ anions are present at high $\mathrm{pH}$ leading to the lower affinity of $\mathrm{Cr}$ (VI) sorption. At $\mathrm{pH}$ values greater than 6 , the presence of $\mathrm{OH}^{-}$ions forms the hydroxyl complexes of chromium. The Cr (VI) species are very soluble in aqueous solutions and their solubility increase with $\mathrm{pH}$. Consequently, the experimental conditions are ideal for solution $\mathrm{pH}$ values of 8 and below.

Modified zeolite and zeolite were examined as soil amendments (SZ: soil-zeolite, SMZ: soil-mod-zeolite) to two types of soil, i.e. sandy loam and silty loam polluted with either beet (Beta vulgaris) or celery plants (Apium graveolens). Before the application of the amendments, soil properties were examined. According to Table 1, both soils are alkaline with normal electrical conductivity and low organic matter. The $\mathrm{Cr}$ adsorption from soils is affected by three major parameters. The first one is the interaction between the positively charged mineral surfaces and chromate anions derived from $\mathrm{Cr}$ (VI) via electrostatic interactions. The second factor is the reduction of $\mathrm{Cr}$ (VI) to $\mathrm{Cr}$ (III) due to the electrons derived from organic matter and Fe (II). The third factor is the adsorption of chromate cations derived from $\mathrm{Cr}$ (III) to soils where $\mathrm{pH}$ plays an important role. High $\mathrm{pH}$ values increase the negative surface sites on soil mineral surface and organic matter leading to increase of $\mathrm{Cr}$ (III) ions adsorption [28]. 
Citation: Brozou E, loannou Z, Dimirkou A (2018) Removal of Cr (VI) and Cr (III) From Polluted Water and Soil Sown with Beet (Beta vulgaris) or Celery (Apium graveolens) after the Addition of Modified Zeolites. Int J Waste Resour 8: 359. doi:10.4172/2252-5211.1000359

Page 5 of 8

Chromium is toxic for most agronomic plants at concentrations equal to $0.5-5 \mathrm{mg} / \mathrm{L}$ in nutrient media and $5-100 \mathrm{mg} / \mathrm{g}$ under soil condition. Usually the concentration of chromium in plants is less than $1 \mu \mathrm{g} / \mathrm{g}$ [29]. According to the World Health Organization (WHO) the maximum permissible limits for the discharge of $\mathrm{Cr}(\mathrm{VI})$ into the inland surface and drinking water are 0.1 and $0.05 \mathrm{mg} / \mathrm{L}$, respectively [29-31] while the acceptable level in soil for the protection of fauna and flaura is estimated to $64 \mathrm{mg} / \mathrm{kg}[32,33]$. The amount of $30 \mathrm{mg} \mathrm{Cr}$ $(\mathrm{VI}) / \mathrm{kg}$, which was added to soils of the present study, is the half of the acceptable level of $\mathrm{Cr}$ (VI) to soils.

The extractable $\mathrm{Cr}$ (VI) values in soils at 90 days after the last contamination of pots with $\mathrm{CrO}_{3}$ were presented in Figure 4 . According to the statistical analysis, the amount of extractable $\mathrm{Cr}$ in both soils cultivated with beet and enriched either with chromium and zeolite (SZ) or chromium and modified zeolite (SMZ) presented significant differences compared to soils with chromium (S) or not (C). Moreover, the statistical analysis in celery shows that the extractable $\mathrm{Cr}$ in both soils enriched with chromium and zeolite (SZ) or chromium and modified zeolite (SMZ) or chromium (S) presented significant differences compared to soils without chromium (C). According to the results, it seems that $\mathrm{Cr}$ (VI) ions in soils increased probably their immobilization in soil when it contains zeolitic amendments. Comparing the treatments SZ and SMZ in both cultivations, it seems that modified zeolite adsorbs chemically $\mathrm{Cr}$ (VI) anions due to the positively charged sites created by its modification with HDTMA and hence they cannot be translocated to the plant.

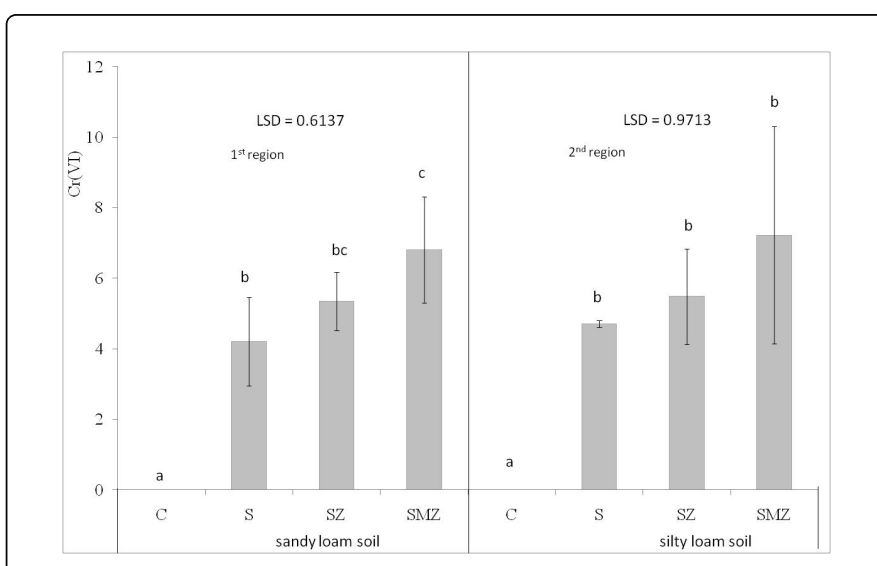

Figure 4: Extractable $\mathrm{Cr}$ in soils which were sown with (a) beet (Beta vulgaris) or (b) celery (Apium graveolens) seeds at different treatments, i.e. C: without chromium, S: with chromium, SZ: with chromium and zeolite, SMZ: with chromium and modified zeolite Within each graph, treatments with different letters have significant differences at $p<0.05$. Bars represent standard errors of the mean of the replicates of each treatment.

The presence of $\mathrm{Cr}$ (III) species to soils that will have the capability to be transferred to plant roots, determined by the creation of complexes between $\mathrm{Cr}$ (III) and diethylenetriaminepentaacetic acid (DTPA) (Figure 5). According to the statistical analysis, the addition of $\mathrm{Cr}$ (VI) in the form of $\mathrm{CrO}_{3}$ to both soils increased significantly the amount of DTPA-Cr (III) complexes in soil with zeolite (SZ) and modified zeolite (SMZ) as amendments in comparison to soil without the addition of $\mathrm{Cr}$ (VI) (C) for both cultivated soils with beet or celery. The presence of $\mathrm{Cr}$ (III) species is due to the reduction of an amount of Cr (VI) to Cr (III) in soil, a mechanism that will be more favorable in acidic conditions and high amounts of organic matter, and in plant roots. At $\mathrm{pH}$ conditions higher than 5.5, as it happens in the present paper $(\mathrm{pH}>8), \mathrm{Cr}$ (III) precipitates from soil solution and forms hydroxides on the soil surface [28]. The differences in the concentrations of DTPA-Cr (III) complexes between S, SZ and SMZ treatments are negligible for both soils and cultivations except for the silty loam soil with zeolite (SZ) cultivated with beet because treatments with the same letter above each column of Figure 5 have no significant differences between them according to the LSD test. According to Figure 5a, zeolite negative surface charge may immobilize Cr (III) ions as chromate cations, while soil with modified zeolite (SMZ) presented lower percentage of negative surface sites compared to zeolite since a ratio of them were neutralized with HDTMA-Br compound and consequently the silty loam soil cultivated with beet presented lower concentrations of DTPA-Cr (III) complexes. Other researchers have shown [34] that the addition of $\mathrm{Cr}$ (VI) increased the concentration of $\mathrm{Cr}$ (III) in acidic soils especially in the lime-amended soil.

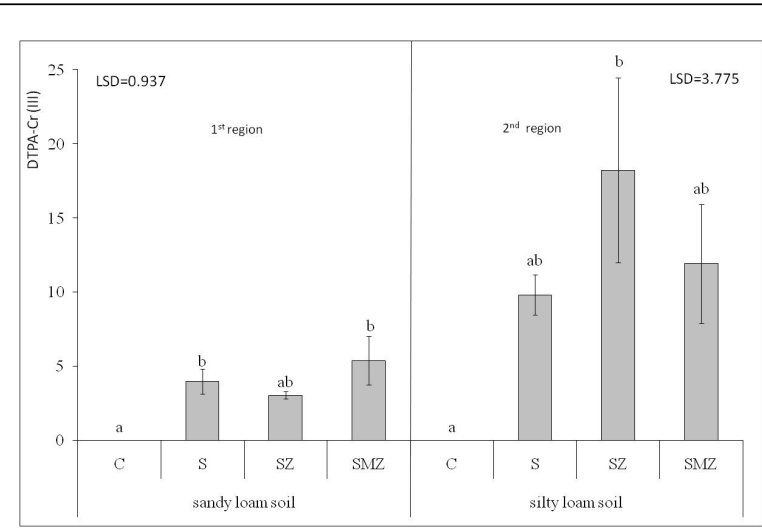

Figure 5: DTPA-Cr(III) (ppm) in soils which were sown with (a) beet (Beta vulgaris) or (b) celery (Apium graveolens) seeds at different treatments, i.e. C:without chromium, S: with chromium, SZ: with chromium and zeolite, SMZ: with chromium and modified zeolite. Within each graph, treatments with different letters have significant differences at $\mathrm{p}<0.05$. Bars represent standard errors of the mean of the replicates of each treatment.

Total chromium in soil (AR-Cr) was determined after the digestion of soil samples with $\mathrm{HCL}-\mathrm{HNO}_{3}$ (Aqua Regia) for the different treatments (Figure 6). According to the statistical analysis, the amount of total chromium in both soils presented non-significant differences among treatments except for the sandy loam soil cultivated with beet as it seems from the letters above the columns of Figure 6, where the LSD test took place. According to the results, it seems that total chromium ranges from 244 to $267 \mathrm{ppm}$ and from 253 to $272 \mathrm{ppm}$ for sandy loam soil cultivated with beet and celery, respectively. Moreover, total chromium in silty loam soils has values 261-286 ppm and 260-279 ppm for beet and celery, respectively. Silty soils restrain higher $\mathrm{Cr}$ amounts compared to sandy soils due to their lower pollutant leaching potential and higher water-holding capacity. 


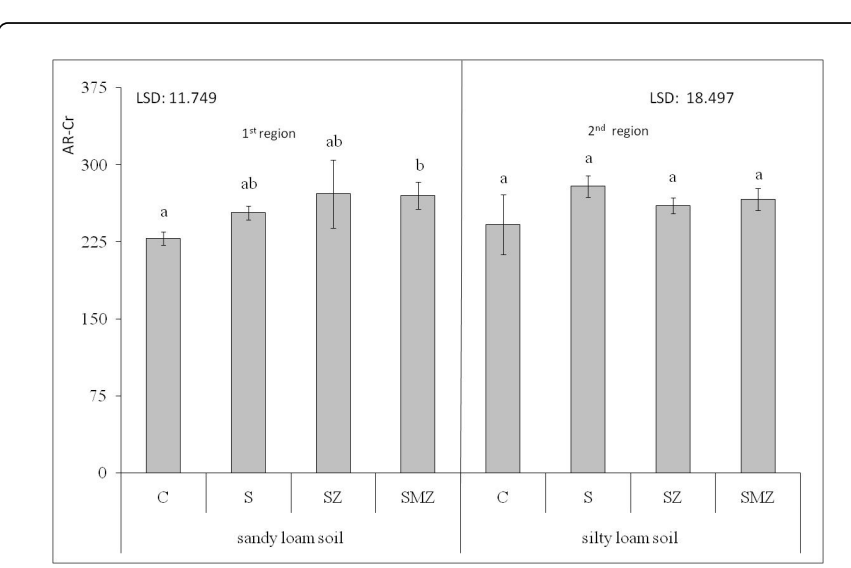

Figure 6: Total $\mathrm{Cr}$ (ppm) in soils which were sown with (a) beet (Beta vulgaris) or (b) celery (Apium graveolens) seeds at different treatments, i.e. C:without chromium, S: with chromium, SZ: with chromium and zeolite, SMZ: with chromium and modified zeolite. Within each graph, treatments with different letters have significant differences at $\mathrm{p}<0.05$. Bars represent standard errors of the mean of the replicates of each treatment.

The analysis of the upper part of beet plants (Figure 7a), which were sown to polluted with Cr (VI) sandy loam soil, has shown $17.7 \%$ decrease of $\mathrm{Cr}(\mathrm{VI})$ concentration in plant tissues developed in soil with zeolite (SZ) and $44.9 \%$ in soil with modified zeolite (SMZ) in comparison with those which developed without soil amendment (S). The analysis of the upper part of beet plants, which were sown to polluted with $\mathrm{Cr}$ (VI) silty loam soil, has shown $8.2 \%$ decrease of $\mathrm{Cr}$ (VI) concentration in plant tissues developed in soil with zeolite (SZ) and $26.98 \%$ in soil with modified zeolite (SMZ) in comparison with those which developed without soil amendment (S). According to the statistical analysis, the amount of Cr (VI) in the upper part of beet plants cultivated to both soils has shown significant differences for all treatments compared to each other as it seems from the different letters above each column in Figure $7 \mathrm{a}$. The Cr percentage differences between the two soils are the result of soil texture. As a result, silty soils with medium porosity and pollutant leaching potential create difficulties to chromate ions' movement to approach plant roots compared to sandy soils. Comparing soils amended with zeolite with those without amendment, it seems that the concentration of $\mathrm{Cr}$ (VI) species to plants in SZ treatment is lower compared to $\mathrm{Cr}$ (VI) concentration to plants in $S$ treatment. The presence of zeolite increased the cation exchange capacity (CEC) of the soil leading to a higher adsorption of chromate ions in the form of $\mathrm{Cr}$ (III) compared to $\mathrm{S}$ treatment. These ions are the result of $\mathrm{Cr}$ (VI) reduction to $\mathrm{Cr}$ (III) decreasing the amount of total $\mathrm{Cr}$ which passes through the roots to plant. Furthermore, soils amended with modified zeolite appeared lower $\mathrm{Cr}(\mathrm{VI})$ concentration in plants in relation to soils amended with zeolite for sandy and silty loam soils, respectively. Modified zeolite increased the cation exchange capacity (CEC) and the anion exchange capacity (AEC) of the soil due to the negative surface sites and the positive HDTMA sites of modified zeolite adsorbing especially chromate ions in the form of $\mathrm{Cr}(\mathrm{VI})$-anions and in a lower extend $\mathrm{Cr}$ (III)-cations. The analysis of the upper part of celery plants (Figure 7b), which were sown to polluted with $\mathrm{Cr}$ (VI) sandy loam soil, has shown $43.7 \%$ decrease of $\mathrm{Cr}$ (VI) concentration in plant tissues developed in soil with zeolite (SZ) and $84.0 \%$ in soil with modified zeolite (SMZ).
The analysis of the upper part of celery plants, which were sown to polluted with $\mathrm{Cr}(\mathrm{VI})$ silty loam soil, has shown $64.1 \%$ decrease of $\mathrm{Cr}$ (VI) concentration in plant tissues developed in soil with modified zeolite (SMZ) in comparison with those which developed in soil with zeolite (SZ) or without soil amendment (S). According to the statistical analysis, the amount of $\mathrm{Cr}$ (VI) in the upper part of celery plants cultivated to sandy loam soil presented significant differences for all treatments compared to each other, while $\mathrm{Cr}$ (VI) concentration in celery plants cultivated to a silty loam soil has shown non-significant differences between $\mathrm{C}$ and SMZ treatments and between S and SZ treatments, respectively, as it seems from the letters above each column in Figure 7b. The order of $\mathrm{Cr}(\mathrm{VI})$ concentration in plants compared to treatments follows: $\mathrm{SMZ}<\mathrm{SZ}<\mathrm{S}$. The results are the same as those described for beet cultivation. The soil without $\mathrm{Cr}$ addition (C) appeared zero and 2.5-3 ppm $\mathrm{Cr}$ (VI) concentration in plant tissues for beet and celery, respectively. Antoniadis et al. [34] studied the influence of $\mathrm{Cr}$ (VI) to Origanum vulgare plants cultivated to an acidic soil amended with peat, lime and zeolite. The addition of $\mathrm{Cr}$ (VI) increased the concentration of $\mathrm{Cr}$ (VI) and $\mathrm{Cr}$ (III) to plants especially in the lime-amended soil. In the lime-amended soil, the plant biomass reduced compared to the control soil due to the reduced amounts of phosphorus in plant and high concentrations of $\mathrm{Cr}$ (VI) in roots. Oregano presented significantly less toxic effects during its cultivation to soil enriched with peat, containing high amounts of organic matter, due to the reduction of $\mathrm{Cr}$ (VI) to Cr (III). Another experiment [35] examined the influence of $\mathrm{Cr}$ (VI) to manure added soil cultivated with spinach. More specifically, the addition of $\mathrm{Cr}$ (VI) ions to pot experiments affected the studied Cr (VI) soil extractability and availability to spinach which was cultivated to soils with natural, synthetic materials and organic matter in the form of farmyard manure. The results have shown that in the manure-amended soil with $\mathrm{Cr}$ (VI), a significant increase in plant dry matter weight, a faster decrease of exchangeable $\mathrm{Cr}$ (VI) in the soil and an acceleration in $\mathrm{Cr}$ (VI) phytoextraction from soil were presented compared to the soil with minerals.

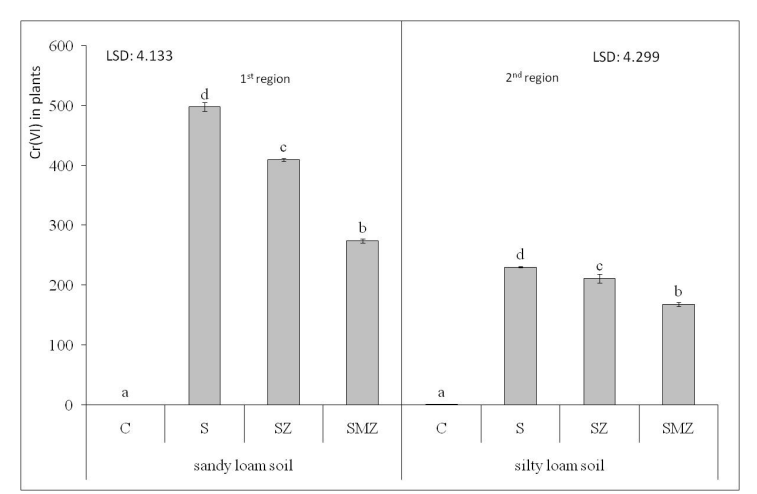

Figure 7: Upper part of $\mathrm{Cr}(\mathrm{VI})$ (ppm) in (a) beet (Beta vulgaris) or (b) celery (Apium graveolens) plants which were sown in soils at different treatments, i.e. C:without chromium, S: with chromium, SZ: with chromium and zeolite, SMZ: with chromium and modified zeolite. Within each graph, treatments with different letters have significant differences at $\mathrm{p}<0.05$. Bars represent standard errors of the mean of the replicates of each treatment.

The analysis of the upper part of beet plants (Figure 8a), which were sown to polluted with $\mathrm{Cr}$ (VI) sandy loam soil, has shown $72.8 \%$ 
increase of $\mathrm{Cr}$ (III) concentration in plant tissues developed in soil with zeolite (SZ) and $78.2 \%$ in soil with modified zeolite (SMZ). The analysis of the upper part of beet plants, which were sown to polluted with $\mathrm{Cr}$ (VI) silty loam soil, has shown $41.5 \%$ increase of $\mathrm{Cr}$ (III) concentration in plant tissues developed in soil with zeolite (SZ) and $53.5 \%$ in soil with modified zeolite (SMZ) in comparison with those which developed without soil amendment (S). According to the statistical analysis, the amount of Cr (III) in the upper part of beet plants cultivated to both soils presented significant differences for all treatments compared to each other. The increase of $\mathrm{Cr}$ (III) in plants is based on the reduction process of $\mathrm{Cr}$ (VI) to $\mathrm{Cr}$ (III), which takes place in soil, in plant roots and especially in leaves. Moreover, comparing different treatments, i.e. S, SZ, SMZ, it seems that the application of zeolitic amendments either zeolite or modified zeolite increases the reduction of $\mathrm{Cr}$ (VI) to $\mathrm{Cr}$ (III) in plants while the total $\mathrm{Cr}$ (=Cr (VI) $+\mathrm{Cr}$ (III) in plants) was diminished in relation to total $\mathrm{Cr}$ in $\mathrm{S}$ treatment with the order $\mathrm{S}>\mathrm{SM}>\mathrm{SMZ}$. According to Figure $8 \mathrm{~b}$, the $\mathrm{Cr}$ (III) concentration of the upper part of celery plants in a sandy loam soil presented a similar behavior with that of beet plants while the $\mathrm{Cr}$ (III) concentration of celery plants in a silty loam soil decreased in the order $\mathrm{S}>\mathrm{SZ}>\mathrm{SMZ}$. It is noticeable that the application of modified zeolite in soil decreases the concentration of $\mathrm{Cr}$ (III) to celery leaves to $3.3 \mathrm{ppm}$ for a silty loam soil. According to literature [36], the impact of geogenic origin chromium uptake by carrots and the risk of their consumption to human health were examined. The results have shown that $\mathrm{Cr}$ was mobilized and adsorbed in the surface and the leaves of carrots cultivated in plot with high carbon content but not in the core of them. The examination of endophytic bacteria revealed their ability to transform $\mathrm{Cr}$ (VI) to $\mathrm{Cr}$ (III) in carrots. Moreover, a site-specific risk assessment analysis indicated no adverse effects to human health due to the consumption of carrots. Another study [37] has examined the immobilization of chromium in the soil and the capacity of Mentha piperita L. to control chromium uptake. It seems that soil has the capacity to immobilize high concentration of Cr. Increasing chromium concentration in the soil, the higher $\mathrm{Cr}$ amounts were observed in the roots than in the upper plant parts indicating that the root system of M. piperita had a large capacity for chromium binding reducing $\mathrm{Cr}$ amounts to the rest plant.

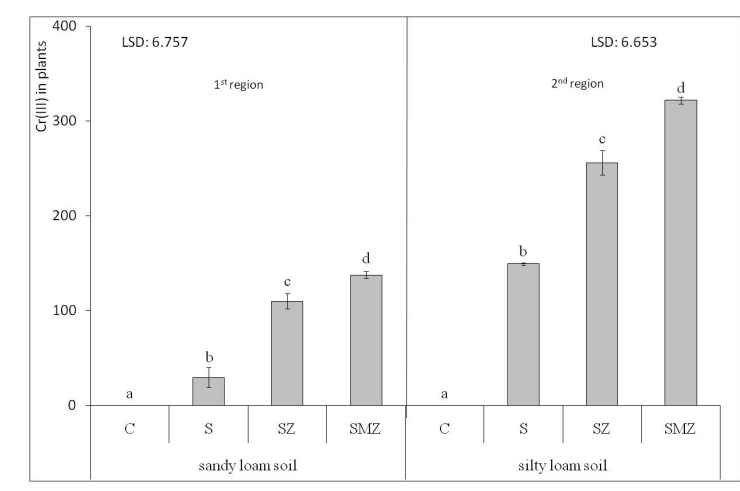

Figure 8: Upper part of $\mathrm{Cr}(\mathrm{III})$ (ppm) in (a) beet (Beta vulgaris) or (b) celery (Apium graveolens) plants which were sown in soils at different treatments, i.e. C:without chromium, S: with chromium, SZ: with chromium and zeolite, SMZ: with chromium and modified zeolite. Within each graph, treatments with different letters have significant differences at $\mathrm{p}<0.05$. Bars represent standard errors of the mean of the replicates of each treatment.

\section{Conclusion}

- Clinoptilolite was modified with hexadecyltrimethylammoniumbromide solution (HDTMA-Br) in a proportion of $1 / 8 \mathrm{w} / \mathrm{v}$ obtaining positive surface exchange sites for the adsorption of chromate anions from aqueous solutions

- The initial Cr (VI) concentration was below $500 \mathrm{mg} / \mathrm{L}$ and the $\mathrm{pH}$ solution values ranged from 7.9 to 8.0 for the adsorbents indicating that $\mathrm{CrO}_{4}{ }^{2-}$ were predominant in the solution and were adsorbed by modified zeolites in the form of (Clin-HDTMA) $)_{2}-\mathrm{CrO}_{4}$

- The kinetic analysis has shown that the chromate anions adsorption capacity reached at $1115.10 \mathrm{mg} / \mathrm{kg}$ for $\mathrm{Z} 1$ and 35.05 $\mathrm{mg} / \mathrm{kg}$ for $\mathrm{Z}$.

- The maximum adsorbed amount of chromate anions was equal to 401.59 and $2000.01 \mathrm{mg} \mathrm{Kg}^{-1}$ for zeolite and modified zeolite, respectively.

- Temperature did not influence the adsorption process indicating that the whole adsorption mechanism is controlled by chemisorption and not by physical adsorption.

- The addition of $\mathrm{Cr}$ (VI) in the two soils did not increase significantly the total chromium in soils.

- $\mathrm{Cr}(\mathrm{VI})$ concentration decreased significantly to the upper part of celery and beet with the addition of soil amendments especially modified zeolite (SMZ)

- The addition of zeolite and modified zeolite in soils did not reduce the amount of $\mathrm{Cr}(\mathrm{VI})$ in soil but chromate ions are probably immobilized by the amendments decreasing ions' concentration to beet and celery plants.

\section{Acknowledgement}

Part of the paper was presented to the $3^{\text {rd }}$ International Congress on Water, Waste and Energy Management.

\section{References}

1. Gheju M, Balcu I (2017) Assisted green remediation of chromium pollution. Journal of Environmental Management 203: 920-924.

2. Novak M, Chrastny V, Sebek O, Martinkova E, Prechova E, et al. (2017) Chromium isotope fractionations resulting from electroplating, chromating and anodizing: Implications for groundwater pollution studies. Applied Geochemistry 80: 134-142.

3. Rathnayake SI, Martens WN, Xi Y, Frost RL, Ayoko GA (2017) Remediation of $\mathrm{Cr}$ (VI) by inorganic-organic clay. Journal of Colloid and Interface Science 490: 163-173.

4. Chen YE, Mao HT, Ma J, Wu N, Zhang CM, et al. (2018) Biomonitoring chromium III or VI soluble pollution by moss chlorophyll fluorescence. Chemosphere 194: 220-228.

5. Swarnakar V, Agrawal N, Tomar R (2011) Sorption of Cr (VI) and As (V) on HDTMA-modified zeolites. International Journal of Scientific and Engineering Research 2: 1-9.

6. Perego C, Bagatin R, Tagliabue M, Vignola R (2013) Zeolites and related mesoporous materials for multi-talented environmental solutions. Microporous and Mesoporous Materials 166: 37-49.

7. Stamatakis MG, Hall A, Hein JR (1996) The zeolite deposits of Greece. Mineral Deposita 31: 473-481.

8. Liu J, Cheng X, Zhang Y, Wang X, Zou Q, et al. (2017) Zeolite modification for adsorptive removal of nitrite from aqueous solutions. Microporous and Mesoporous Materials 252: 179-187.

9. de Gennaro B, Catalanotti L, Bowman RS, Mercurio M (2014) Anion exchange selectivity of surfactant modified clinoptililote-rich tuff for environmental remediation. Journal of Colloid and Interface Science 430: $178-183$. 
Citation: Brozou E, loannou Z, Dimirkou A (2018) Removal of $\mathrm{Cr}$ (VI) and $\mathrm{Cr}$ (III) From Polluted Water and Soil Sown with Beet (Beta vulgaris) or Celery (Apium graveolens) after the Addition of Modified Zeolites. Int J Waste Resour 8: 359. doi:10.4172/2252-5211.1000359

Page 8 of 8

10. Reeve PJ, Fallowfield HJ (2018) Natural and surfactant modified zeolites: A review of their applications for water remediation with a focus on surfactant desorption and toxicity towards microorganisms. Journal of the Environmental Management 205: 253-261.

11. Chao HP, Chen SH (2012) Adsorption characteristics of both cationic and oxyanionic metal ions on hexadecyltrimethylammonium bromidemodified NaY zeolite. Chemical Engineering Journal 193-194: 283-289.

12. Bowman RS, Sullivan EJ, Li Z (2000) Uptake of cations, anions and nonpolar organic molecules by surfactant - modified clinoptilolite - rich tuff in: Natural Zeolites for the Third Millennium 287-297.

13. Chaudhry SA, Khan TA, Ali I (2017) Equilibrium, kinetic and thermodynamic studies of $\mathrm{Cr}$ (VI) adsorption from aqueous solution onto manganese oxide coated sand grain (MOCSG). Journal of Molecular Liquids 236: 320-330.

14. Ure AM (1995) Methods of analysis for heavy metala in soils. In B.J. Alloway (Ed.), Heavy metals in soils. Blackie Academic and Professional, London 58-102.

15. Lindsay WL, Norvell WA (1978) Development of a DTPA soil test for zinc, iron, manganese and copper. Soil Science Society of America Journal 42: 421-428.

16. Argiri A, Ioannou Z, Dimirkou A (2013) Impact of new soil amendments on the uptake of lead by crops, Communications in Soil Science and Plant Analysis 44: 566-573.

17. Ott RL, Longnecker M (2001) An introduction to statistical methods and data analysis, Brooks/Cole, Cengage Learning.

18. Jorfi S, Ahmadi MJ, Pourfadakari S, Jaafarzadeh N, Soltani RDC, et al. (2017) Adsorption of Cr (VI) by natural clinoptilolite zeolite from aqueous solutions: Isotherms and Kinetics. Polish Journal of Chemical Technology 19: 106-114.

19. Brozou E, Ioannou Z, Antoniadis V, Dimirkou A (2013) Adsorption of hexavalent chromium from aqueous solutions onto modified zeolites, Proceedings of the 13th International Conference of Environmental Science and Technology, 5-7 September 2013, Athens, Greece.

20. Dautoo UK, Shandil Y, Chauhan GS (2017) New crosslinked hydrazidebased polymers as $\mathrm{Cr}$ (VI) ions adsorbents. Journal of Environmental Chemical Engineering 5: 5815-5826.

21. Abdelnaeim MY, El Sherif IY, Attia AA, Fathy NA, El-Shahat MF (2016) Impact of chemical activation on the adsorption performance of common reed towards $\mathrm{Cu}$ (II) and Cd (II). International Journal of Mineral Processing 157: 80-88.

22. Kim HM, Kim JG, Cho JD, Hong JW (2003) Optimization and characterization of UV-curable adhesives for optical communication by response surface methodology. Polymer Testing 22: 899-906.

23. Ioannou Z, Papapostolou T, Georgoulas N, Dimirkou A (2012) Use of modified zeolites for the remediation of waters and cultivated soils from $\mathrm{Cu}$ (II). Water Air \& Soil Pollution 223: 5841-5854.
24. Yusof AM, Malek NANN (2009) Removal of Cr (VI) and As (V) from aqueous solutions by HDTMA-modified zeolite Y. Journal of Hazardous Materials 162: 1019-1024.

25. Baes CF, Mesmer RE (1976) The hydrolysis of cations, John Wiley and Sons, New York.

26. Krishna BS, Murty DSR, Jai Prakash BS (2001) Surfactant-modified clay as adsorbent for chromate. Applied Clay Science 20: 65-71.

27. Li Z, Bowman RS (1997) Counterion effects on the sorption of cationic surfactant and chromate on natural clinoptilolite. Environmental Science and Technology 31: 2407-2412.

28. Stewart MA, Jardine PM, Brandt CC, Barnett MO, Fendorf SE, et al. (2003) Effects of contaminant concentration, aging and soil properties on the bioaccessibility of Cr (III) and Cr (VI) in soil. Soil and Sediment Contamination 12: 1-21.

29. Sinha V, Pakshirajan K, Chaturvedi R (2018) Chromium tolerance, bioaccumulation and localization in plants: An Overview. Journal of Environmental Management 206: 715-730.

30. Forstner U, Wittmann GT (2012) Metal pollution in the aquatic environment, Springer-Verlag, Berlin, Heidelberg, New York.

31. Politi MA, Atjian MC, Amoroso MJ, Abate CM (2011) Soil chromium bioremediation: synergic activity of actinobacteria and plants. International Biodeterioration and Biodegradation 65: 1175-1181.

32. Canadian Council of Ministers of the Environment (2015) Canadian Soil Quality Guidelines for the Protection of Environmental and Human Health. Scientific criteriadocument.

33. Lukina AO, Boutin C, Rowland O, Carpenter DJ (2016) Evaluating trivalent chromium toxicity on wild terrestrial and wetland plants. Chemosphere 162: 355-364.

34. Antoniadis V, Zanni A, Levizou E, Shaheen SM, Dimirkou A, et al. (2018) Modulation of hexavalent chromium toxicity on Origanum vulgare in an acidic soil amended with peat, lime and zeolite. Chemosphere 195: 291-300.

35. Molla K, Dimirkou A, Antoniadis V (2012) Hexavalent chromium dynamics and uptake in manure-added soil. Water Air and Soil Pollution 223: 6059-6067.

36. Lilli MA, Syranidou E, Palliou A, Nikolaidis NP, Karatzas G, et al. (2017) Assessing the impact of geogenic chromium uptake by carrots (Daucus carota) grown in Asopos river basin. Environmental Research 152: 96-101.

37. Razic S, Dogo S (2010) Determination of chromium in Mentha Piperita L. and soil by graphite furnace atomic absorption spectrometry after sequential extraction and microwave assisted acid digestion to assess potential bioavailability. Chemosphere 78: 451-456. 